\title{
SOLVENT EXTRACTION OF IRON IONS FROM HYDROCHLORIC ACID SOLUTIONS
}

\author{
RANIA FAROUQ ${ }^{I^{*}}$, YEHIA SELIM ${ }^{1}$ \\ ${ }^{1}$ Petrochemical Engineering Department, Pharos University, Alexandria, Egypt \\ (+203)3877200, (+203)3877400, (+203)3877212, (+203)3877214; Canal El Mahmoudeya St. Semouha, Alexandria, Egypt.
}

\begin{abstract}
In this study Methyl Isobutyl Ketone (MIBK) and acetophenone (Methyl Phenyl Ketone) are presented as suitable agents for removal of Fe(III) from concentrated hydrochloric acid solutions.

An extensive study applying 4 parameters was carried out: Time (5, 10,15,20,30 and 60 minutes), Stirring rate (200, 300,400 and 500 r.p.m), Solvent to HCl Ratio $(5 \%, 10 \%, 14 \%$ and $16 \%)$, and initial concentration of Fe ions in crude $\mathrm{HCl}(95.24,126 \mathrm{ppm}, 330 \mathrm{ppm}$ and 1955 ppm).The best Condition was found to be 30 min -400 r.p.m $-14 \%$.

The distilled water was used to strip Fe ions out of MIBK; In order to get most of the MIBK dissolved in both the concentrated HCl and water. Diluents were used such as benzene, kerosene and xylene. Xylene gives better recovery of about $96 \%$.
\end{abstract}

Key words: Fe(III); Solvation mechanism; Hydrochloric acid; MIBK ;acetophenone

\section{INTRODUCTION}

Heavy metal pollution is a serious environmental problem. Iron ions are one of the heavy metals that cause serious problems in the aqueous streams especially at high levels concentration [1]

Iron (III) is present in the solutions after hydrometallurgical processes of recovering a number of nonferrous metal ions. Hydrochloric acid $(\mathrm{HCl})$ enriched with iron ions is produced during the synthesis of PVC; hence has lower value than traditional hydrochloric acid. In order to produce high purity hydrochloric acid; an effective means to remove it from the pregnant solutions is often Desirable. [2]

Traditional processes used for treating effluents with heavy metals, include: ion exchange, reverse osmosis, chemical coagulation and precipitation, ultrafiltration, and adsorption. [3-6]

It was found that the adsorption process can be effective in heavy metal removal. In addition to that, the natural adsorbents are environmental friend, existent in large quantities and have good adsorption properties. [7-8]

From literature it was found that solvent extraction and ion exchange are being employed for iron control. [9-10] However solvent extraction processes have become major purification operations in practice [11-13] There are a few research reports on the use of a solvent extraction approach to recover Fe (III) from chloride solutions; the solvent includes various amines and quaternary ammonium salts; Extraction using immiscible solvents containing carbonyl group or Polyethers give very good results but it dissolves to higher rate starting from $6 \mathrm{~N}$ concentrations hydrochloric acid. [14-19]

The present work examines the possibility of iron (III) separation from hydrochloric acid solution by solvent extraction using MIBK at various initial metal concentrations and MIBK ratios.

\section{Chemicals \& Reagents}

All chemicals were used as delivered without any purification.

Two liquids, i.e.,MIBK (Methyl Isobutyl Ketone: 4-Methyl 2- Pentanone) From SDFCL s d fine chemicals (India) Assay: 99.0 min. Sp.Gr. : 0.80 g/ml and acetophenone (Methyl Phenyl Ketone From Alpha chemicals. Assay: $98 \%$ min. Sp.Gr:1.026; were used as metal ion carriers in solvent extraction; benzene, kerosene and xylene as diluents. MIBK was used as 10, 12, 14 and 16 vol. \% solution.

The spent acid was a yellow solution with the concentration $11 \mathrm{M}$ and iron concentration range from 95 to $1955 \mathrm{mg} / \mathrm{L}$

3. Liquid-liquid extraction procedure

Extraction was carried out in a typical way: aqueous sample, containing metal ions in $11 \mathrm{M} \mathrm{HCl}$ were mechanically shaken with MIBK for differen time periods at $\left(25 \pm 1^{\circ} \mathrm{C}\right)$ and then transferred into glass separator funnels and then allowed to stand for phase separation of suitable volume.

Scrubbing of loaded MIBK, was carried out with deionized water. Stripping was carried out four times consecutively using fresh water each time. Aqueous phases after each stage were taken for analysis.

Benzene, kerosene and xylene were applied as diluents. All tests were carried out at room temperature $\left(25 \pm 1^{\circ} \mathrm{C}\right)$ to eliminate any temperature effects.
Percentage extraction (E) was calculated from the contents of metal ions in the aqueous Phases before $\left(\mathrm{C}_{\mathrm{o}}\right)$ and after $(\mathrm{C})$ extraction:

$$
C^{*}=\frac{\left(V_{i} \cdot C_{i}\right)-\left(V_{w}^{*} \cdot C_{w}^{*}\right)}{V_{0}^{*}}
$$

Concentrations of iron ions in the organic phase were calculated from mass balance taking into account the change of phase volume, if necessary:

$$
E=\frac{C_{0}-C}{C_{0}} .100 \%
$$

\section{RESULTS AND DISCUSSION}

Batch experiments of liquid-liquid extraction of Fe (III) were carried out to verify transport of the iron species with MIBK and acetophenone.

\subsection{Effect of different time intervals on \% extraction}

The percentage extractions of the $\mathrm{Fe}^{3+}$ ion from the high-level $(125 \mathrm{ppm})$ aqueous solution for different time periods of MIBK are given in Table 1 .

Table 1. Percentage extraction of Fe ions at different time period of MIBK

\begin{tabular}{|c|c|c|}
\hline Time & Ce & \% extraction \\
\hline 5 & 5.27 & 98.39 \\
\hline 10 & 4.95 & 98.49 \\
\hline 20 & 1.66 & 99.49 \\
\hline 30 & 3.04 & 99.58 \\
\hline 60 & 3.09 & 99.54 \\
\hline
\end{tabular}

As shown from table increasing the time from 30 to 60 min has slight effect on $\%$ extraction; so time 20 was chosen as optimum time period.

\subsection{Effect of different MIBK ratios}

The percentage extraction of the $\mathrm{Fe}^{3+}$ ion from the high-level $(125 \mathrm{ppm})$ aqueous solution using different concentrations of MIBK (10,12,14 and 16\%) at constant contact time 15 and 60 min are given in Table 2 . 
Table 2. Percentage extraction of Fe ions using different MIBK ratios.

\begin{tabular}{|c|c|c|}
\hline MIBK concentration & $\begin{array}{c}\text { \%extraction (at 15 } \\
\text { min) }\end{array}$ & $\begin{array}{c}\text { \%extraction (at 60 } \\
\text { min) }\end{array}$ \\
\hline $10 \%$ & 89.08 & 91.98 \\
\hline $12 \%$ & 94.75 & 96.92 \\
\hline $14 \%$ & 94.83 & 97.54 \\
\hline $16 \%$ & 94.98 & 97.26 \\
\hline
\end{tabular}

It is observed that from the MIBK ratio of $12 \%$ that the extraction is nearly constant; However MIBK ratio of $14 \%$ was chosen as optimum concentration.

\subsection{Effect of different stirring speed}

The Percentage extractions of the $\mathrm{Fe}^{3+}$ ion from the high-level (125ppm) aqueous solution for different stirring speed of MIBK are given in Table 3 .

Table 3. Percentage extraction of Fe ions at different stirring speed with MIBK.

\begin{tabular}{|c|c|c|}
\hline r.p.m & Ce & \% extraction \\
\hline 100 & 13.53 & 95.89 \\
\hline 200 & 12.58 & 96.18 \\
\hline 300 & 4.79 & 98.54 \\
\hline 400 & 2.95 & 99.10 \\
\hline 500 & 11.21 & 96.60 \\
\hline
\end{tabular}

As shown from table increasing the R.P.M from 100 to 400 increases \% extraction then decreases; so time 400 R.P.M was chosen as optimum speed of agitation.

\subsection{Effect of initial concentrations of iron (III)} (III).

Table 4. Percentage extraction at different initial concentrations of iron

\begin{tabular}{|c|c|c|}
\hline $\mathbf{C i}(\mathbf{m g} / \mathbf{L})$ & $\mathbf{C e}(\mathbf{m g} / \mathbf{L})$ & \% extraction \\
\hline 95.24 & 2.45 & 97.42 \\
\hline 125.9 & 3.04 & 97.58 \\
\hline 329.7 & 2.95 & 99.10 \\
\hline 1955 & 0.43 & 99.97 \\
\hline
\end{tabular}

As shown from table 4 increasing the initial concentrations of iron (III) from 95.24 to $1955 \mathrm{ppm}$ has increased \% extraction.

\subsection{Effect of the diluents on the extraction of iron (III)}

In order to get most of the MIBK dissolved in both Conc. $\mathrm{HCl}$ and water we used diluents such as kerosene, Benzene and Xylene. Table 5 shows the percent of iron (III) carried out in several combinations of the MIBK and the diluent.

Table 5. Percentage extraction of different combinations of the MIBK and the diluents.

\begin{tabular}{|c|c|c|c|c|}
\hline Diluent & $\begin{array}{c}\text { Volume } \\
\text { before } \\
\text { extraction }\end{array}$ & $\begin{array}{c}\text { Volume } \\
\text { after } \\
\text { extraction }\end{array}$ & \%loss & \%Extraction \\
\hline Kerosene & $20 \mathrm{~mL}$ & $9 \mathrm{~mL}$ & $52.5 \%$ & 92.11 \\
\hline Benzene & $150 \mathrm{~mL}$ & $129 \mathrm{~mL}$ & $14 \%$ & 99.10 \\
\hline Xylene & $250 \mathrm{~mL}$ & $240 \mathrm{~mL}$ & $4 \%$ & 99.47 \\
\hline
\end{tabular}

By comparing total volume of the solvent with the different diluents, it is observed that Xylene gives better recovery of about $96 \%$ of MIBK with high percent of extraction.
4.6. Comparison of the extraction of iron (III) using Acetophenone and MIBK

Two successive extraction-stripping stages were carried out with MIBK and Acetophenone using fresh aqueous solutions of about $2000 \mathrm{mg} / \mathrm{L} \mathrm{Fe} \mathrm{(III)}$ in $\mathrm{HCl} 11 \mathrm{M}$

Table 6. The extraction of iron (III) using Acetophenone and MIBK

\begin{tabular}{|c|c|c|}
\hline Stages & Acetophenone & MIBK \\
\hline 1 & 99.95 & 99.97 \\
\hline 2 & 99.45 & 99.04 \\
\hline
\end{tabular}

As shown from Table 6 MIBK extraction is slightly higher than for Acetophenone for iron (III) concentration about $2000 \mathrm{mg} / \mathrm{L} \mathrm{HCl}$. Therefore, the substitution of MIBK with acetophenone, as an iron (III) extractant from hydrochloric acid solutions, seems to be useless. Moreover, acetophenone is more expensive than MIBK.

\subsection{Extractant re-utilization}



Fig.1. Fe (III) extraction from $\mathrm{HCl}$ in four successive extraction-water stripping stages by MIBK.

In order to collect information on the stability of the MIBK for the adopted experimental conditions, four successive extraction-stripping stages were carried out with MIBK, using fresh aqueous solutions of a $95.24 \mathrm{mg} / \mathrm{L} \mathrm{Fe}$ (III) in $\mathrm{HCl} 11 \mathrm{M}$. The results obtained for the Fe (III) extraction in each stage, Fig. 1. Clearly denote that the re-utilization of the MIBK is feasible, since no significant decrease of Fe (III) extraction is observed after the successive contacts. A similar behavior is expected for the acetophenone extractant described in this work as shown in Fig. 2.

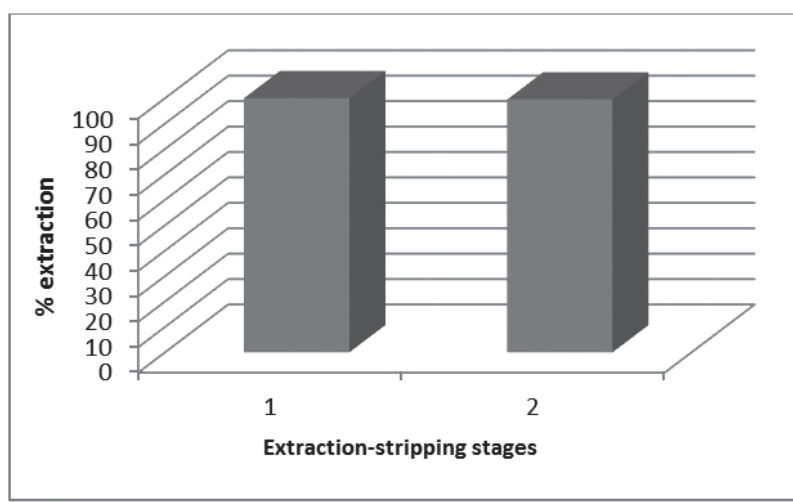

Fig. 2. $\mathrm{Fe}$ (III) extraction from $\mathrm{HCl}$ in four successive extraction-water stripping stages by acetophenone.

5. Conclosion

The solvent extraction of iron (III) was carried out from hydrochloric acid media using MIBK and acetophenone. Both solvents can be successfully used for removing iron(III) ions from aqueous solution. The maximum removal 
percentages of iron(III) ions using both solvents are achieved within the first 20 min. The removal percentages of iron(III) ions increase sharply by increasing solvent ratios up to $14 \%$. As the initial concentration of ions increases the percentage removal using MIBK increases at stirring speed 400 r.p.m.

Using Xylene as solvent stripper giving better result than benzene but it is more expensive.

\section{REFERENCES}

1. Al-Anber M., Removal of high-level $\mathrm{Fe}^{3+}$ from aqueous solution using natural inorganic materials: Bentonite (NB) and quartz (NQ), Desalination 2010;250 885-891

2. Jafari A. and John Donaldson D,Determination of $\mathrm{HCl}$ and $\mathrm{VOC}$ Emission from Thermal Degradation of PVC in the Absence and Presence of Copper, Copper(II) Oxide and Copper(II) Chloride, E-Journal of Chemistry 2009; 6(3); 685-692

3. Chaturvedi S, Dave P,Removal of iron for safe drinking water, Desalination $2012 ; 303$ 1-11

4. M.F. SanRoma' n, I.OrtizGa' ndara, R.Iban ez, I.Ortiz ,Hybrid membrane process for the recovery of major components (zinc, iron and $\mathrm{HCl}$ ) from spent pickling effluents, Journal of Membrane Science 2012;415-416 616-623

5. Cieszynska A, Wisniewski M,Selective extraction of palladium(II) from hydrochloric acid solutions with phosphonium extractants, Separation and Purification Technology $2011 ; 80 ; 385-389$

6. Niemczewska J, Cierpiszewski R, Szymanowski J, Mass transfer of zinc(II) extraction from hydrochloric acid solution in the Lewis cell, Desalination 2004; 162 169-177

7. El-Zahhar A, Sharaf El-Deen S, Sheha R, Sorption of iron from phosphoric acid solution using polyacrylamide grafted activated carbon, Journal of Environmental Chemical Engineering 2013; 290-299

8. Navarro R, Gallardo V, Saucedo I, E. Guibal,Extraction of Fe(III) from hydrochloric acid solutions using Amberlite XAD-7 resin impregnated with trioctylphosphine oxide (Cyanex 921), Hydrometallurgy $2009 ; 98$ 257-266

9. Lee M, Nicol M, Removal of iron from cobalt sulfate solutions by ion exchange with Diphonix resin and enhancement of iron elution with titanium(III), Hydrometallurgy 2007; 86 6-12
10. Regel-Rosocka M, Nowak $Ł$, Wis'niewski M, Removal of zinc (II) and iron ions from chloride solutions with phosphonium ionic liquids, Separation and Purification Technology 2012; 97 158-163.

11. Sayar N, Filiz M, Sayar A, Extraction of $\mathrm{Zn}(\mathrm{II})$ from aqueous hydrochloric acid solutions into Alamine 336-m-xylene systems. Modeling considerations to predict optimum operational conditions, Hydrometallurgy 2007;86 27-36

12. Kinoshita T, Akita S, Nii S, Kawaizumi F, Takahashi K, Solvent extraction of gallium with non-ionic surfactants from hydrochloric acid solution and its application to metal recovery from zinc refinery residues, Separation and Purification Technology 2004; 37 127-133

13. Baba A, Adekola F, Solvent extraction of $\mathrm{Pb}(\mathrm{II})$ and $\mathrm{Zn}$ (II) from a Nigerian galena ore leach liquor by tributylphosphate and bis(2,4,4 trimethylpentyl) phosphinic acid, Journal of King Saud University - Science 2013; 25, 297-305

14. Hariharan A, Sudhakar Ch, and Venkateswara Rao B,Solvent extraction of Iron (III) with Tetra butyl ammonium bromide from aqueous acid solutions, International Journal of Analytical and Bioanalytical Chemistry 2013; 3(3): 78-81

15. Paiva A, Costa M, Application of N,NV-tetrasubstituted malonamides to the recovery of iron(III) from chloride solutions, Hydrometallurgy 77 (2005) 103-108

16. Grzeszczyk A, Regel-Rosocka M ,Extraction of zinc(II), iron(II) and iron(III) from chloride media with dibutylbutylphosphonate, Hydrometallurgy 2007; 86 72-79

17. Xiaomei Wang, Bin Liang, Li Lü, Pan Wu, Chun Li, Jin Ma,Simultaneous oxidation and extraction of iron from simulated ilmenite hydrochloric acid leachate] , Hydrometallurgy 2012;129-130 105-110

18. Rabah M,Recovery of iron and copper from spent $\mathrm{HCl}$ used to clean up dirty car radiators, Hydrometallurgy 2000;56.75-92

19. Baba A, Adekola F, Arodola O, Ibrahim L, Bale R, Ghosh M, Sheik A ,Simultaneous Recovery Of Total Iron And Titanium From Ilmenite Ore By Hydrometallurgical Processing, Metall. Mater. Eng. 2012;Vol 18 (1) p. 67-78.

20. Rydberg J, Solvent Extraction Principles and Practice, Revised and Expanded, CRC Press, 2004 